\title{
Physiochemical analysis and centesimal composition of Pleurotus ostreatus mushroom grown in residues from the Amazon
}

\author{
Análise físico-química e composição centecimal do cogumelo \\ Pleurotus ostreatus cultivado em resíduos da Amazônia
}

Ceci SALES-CAMPOS ${ }^{1}$, Lidia Medina ARAUJO ${ }^{2}$, Marli Teixeira de Almeida MINHONI,
Meire Cristina Nogueira de ANDRADE ${ }^{3 *}$

\begin{abstract}
The objective of the present work was to evaluate the nutritional composition of mushrooms produced in alternative substrates in agricultural and agro-industrial residues from the Amazon. $\mathrm{C}, \mathrm{N}, \mathrm{pH}$, moisture, soluble solids, protein, lipids, total fibers, ashes, carbohydrates and energy were determined. Substrates were formulated from Simarouba amara Aubl. and Ochroma piramidale Cav. ex. Lam. Sawdust and from Bactris gasipaes Kunth and Saccharum officinarum stipe. Results showed that the nutritional composition of $P$. ostreatus varied according to the cultivation substrate and that it can be considered important food due to its nutritional characteristics such as: high protein content; metabolizable carbohydrates and fiber; and low lipids and calories contents.
\end{abstract}

Keywords: edible mushroom; nutritional value; minerals; protein; fiber.

\section{Resumo}

O presente estudo teve como objetivo avaliar a composição nutricional dos cogumelos produzidos em substratos alternativos à base de resíduos agrícolas e agroindustriais da Amazônia. Determinou-se C, N, pH, umidade, sólidos solúveis, proteína, lipídios, fibra total, cinzas, carboidratos e energia. Os substratos foram formulados a partir de serragem de Simarouba amara Aubl. (marupá), Ochroma piramidale Cav. ex. Lam. (pau de balsa) e do estipe de Bactris gasipaes Kunth (pupunheira) e de Saccharum officinarum (cana-de-açúcar). Os resultados demonstraram que: a composição nutricional do $P$. ostreatus variou com o substrato de cultivo e; $\mathrm{O} P$. ostreatus pode ser considerado um importante alimento devido suas características nutricionais: altos teores de proteínas, carboidratos metabolizáveis e fibras; baixos teores de lipídios e de calorias. Palavras-chave: cogumelo comestivel; valor nutricional; minerais; proteína; fibra.

\section{Introduction}

The consumption of Agaricus bisporus Lange (champignon), Lentinula edodes (shiitake) and some Pleurotus - the main mushroom species grown in Brazil, has been growing significantly (MINHONI et al., 2007). However, this relative availability is still restricted mostly to the Southeastern and Southern regions of the country.

Also, the use of some species as tea or capsules as nutraceuticals has accelerated the production of mushrooms. Nevertheless, there are few studies about the nutritional composition of these mushrooms, resulting in a lack of investment in research to evaluate the quality of this food (FURLANI, 2004).

The composition of the species according to the substrate is important when we study the viability of mushroom cultivation in alternative substrates. The Pleurotus genus is considered a primary decomposer of wood and plant residue (KURTZMAN; ZADRAZIL, 1982) and is widely grown in tropical and subtropical weather, and it can be artificially cultivated (AKINDAHUNSI; OYETAYO, 2006). They are likely to be grown in a variety of residues, such as agricultural, agroindustrial and wood residues.

Pleurotus mushrooms, such as $P$. ostreatus, have increased gastronomic value; are rich in proteins, vitamins, fibers, carbohydrates and several minerals; are poor in lipids (STURION; OETTERER, 1995; WANG; SAKODA; SUZUKI, 2001; SILVA; COSTA; CLEMENTE, 2002; FURLANI, 2004; SAPATA, 2005); and have medicinal properties (COCHRAN, 1978; SMITH; ROWAN; SULLIVAN, 2002).

There is great variability in the nutritional composition of mushrooms among the same species and among different species (FASIDI; EKUERE, 1993; STURION; OETTERER, 1995; WANG; SAKODA; SUZUKI, 2001; SILVA; COSTA; CLEMENTE, 2002; FURLANI, 2004; SAPATA, 2005; DAS; MUKHERJEE, 2007). These variations are due to the mushroom

\footnotetext{
Received 13/7/2009

Accepted 23/1/2010 (004313)

${ }^{1}$ Instituto Nacional de Pesquisas da Amazônia - INPA, Coordenação de Pesquisas em Produtos Florestais, Manaus - AM, Brasil

2 Universidade Federal do Amazonas - UFAM, Manaus - AM, Brasil

${ }^{3}$ Departamento de Produção Vegetal, Módulo de Cogumelos, Faculdade de Ciências Agronômicas, Universidade Estadual Paulista - UNESP,

Rua José Barbosa de Barros, 1780, Fazenda Lageado, CP 237, CEP 18610-307, Botucatu - SP, Brasil, E-mail: mcnandrade@hotmail.com

${ }^{*}$ Corresponding author
} 
species chosen, strains, kind of substrate used, maturation degree, type of storage, analyzed parts and conservation procedure (CRISAN; SANDS, 1978; FURLANI, 2004).

The objective of the present study was to evaluate the nutritional composition of mushrooms using agricultural and agro-industrial residues from the Amazon as substrates.

\section{Materials and methods}

The study was carried out at the Laboratory of Soils and Plants Analyses and the Fishing Laboratory of the Research Coordination of Forest Products (CPPF) of the Amazon National Research Institute (INPA) and at the Analytical Central of the Federal University of 'Amazonas'.

The wood residue was originated from the local wood industry. The agro-industrial residues came from microindustries producing sugar cane juice and Bactris gasipaes Kunth stipe resulted from heart-of-palm production. Collection, drainage and preparation of the material were carried out at the CPPF/INPA.

Simarouba amara Aubl. and Ochroma piramidale Cav. ex. Lam sawdust was used in the preparation of the substrate. The agro-industrial residues came from Saccharum officinarum (crushed sugar cane) and Bactris gasipaes Kunth. All samples were dehydrated in a solar dryer at CPPF/INPA and packed separately in $100 \mathrm{~L}$ plastic deposits until the substrate preparation for the test with the fungus, according to Sales-Campos (2008).

Substrates with both wood and agro-industrial residues were individually prepared. Each substrate was re-humidified to around $70 \%$ and added with $2 \%$ calcium carbonate (in relation to dry weight) to keep pH around 6.5. Next, substrates were placed inside glass bottles and sterilized below $121^{\circ} \mathrm{C}$ for one hour. After inoculation in aseptic conditions, incubation was performed inside a climatic chamber for one month, at the temperature of $25 \pm 2{ }^{\circ} \mathrm{C}$ and relative humidity of $80-85 \%$, until primordia emission, when the temperature of the chamber was reduced to $25-22{ }^{\circ} \mathrm{C}$ and the relative humidity was changed to $85-90 \%$. A thermal $\left(20^{\circ} \mathrm{C}\right)$ and hydrous shock was applied after the first flow, in order to induce another fructification.

After cultivation, mushroom samples were arranged according to collection source (substrate) and codified according to the residue used as substrate: SIAMP (Simarouba amara Aubl.); SIAPB (Ochroma piramidale Cav. ex. Lam.); SIAPP (Bactris gasipaes Kunth) and SIACN (Saccharum officinarum crushed sugar cane).

Mushrooms from each substrate were homogenized and dried in stove with circulating air at $55^{\circ} \mathrm{C}$.

The determination of mushrooms $\mathrm{pH}$ was performed using a previously calibrated potentiometer with 7 and 4 buffers, according to the methodology recommended by A.O.A.C. (1997).

The organic carbon was determined by the Walkley Black method, according to Mendonça and Matos (2005).

The Kjeldahl method was used for total nitrogen analysis in three stages: digestion, distillation and titration (MALAVOLTA et al. 1989; A.O.A.C., 1997).
Considering that $100 \mathrm{~g}$ of protein contain an average of $16 \%$ nitrogen, the following formula was used to convert nitrogen into protein: Protein $\%=\mathrm{N} \% \times 4.38$ for mushrooms.

Water activity (Wa) in mushrooms was determined by using a Pawkit water activity analyzer with calibration and adjustment technical certificate (BRASEQ, 2005).

The refraction index of the sugar solution contained in raw matter, formulated substrates and mushrooms was measured by means of refractometry. Samples were homogenized and diluted in distilled water and big particles were discarded. 1 to 2 drops were transferred to the refractometer prism and read in the Brix ${ }^{\circ}$ scale (CARVALHO et al., 2002).

The humidity content of samples mentioned was obtained by dissection method in stove at $105^{\circ} \mathrm{C}$, until mass was constant. One gram of each crushed sample was weighed with $0.01 \mathrm{mg}$ analytical scale (three repetitions per sample), inside previously tared crucible; the material was dried in stove at $105^{\circ} \mathrm{C}$ for four hours. After that, crucibles were transferred to a dissector with dehydrator (silica) and cooled down to environment temperature; next, they were weighed and the procedure was repeated until mass was constant.

Dissected samples were submitted to extraction with cold solvents mixtures by means of the Bligh and Dyer method in triplicates, with chloroform, methanol and water as solvents. The lipids amount was obtained by weighing and the results are expressed in grams per $100 \mathrm{~g}$ of sample (CARVALHO et al., 2002).

The total fiber content was determined by the Weende method (ASSOCIATION..., 1997). Then, samples were submitted to alkaline digestion in $1.25 \% \mathrm{NaOH}$ solution medium.

The ashes content of a sample corresponds to the fixed mineral residue obtained after the decomposition of all organic components. The analysis comprised dissection of samples, weighing of about $1 \mathrm{~g}$ in triplicate, carbonization and calcination in muffle at $5500^{\circ} \mathrm{C}$. The results were expressed in $\%$ (ASSOCIATION..., 1997).

The total carbohydrates content was obtained by means of subtraction (100 - total grams of humidity, protein, lipids and ashes), including fiber fraction. The result is given in percentage values (LA RED..., 2002; UNIVERSIDADE..., 2006).

The available carbohydrates content was obtained through subtraction, excluding fiber fraction (100 - total grams of humidity, protein, lipids, ashes and fiber) (LA RED..., 2002; UNIVERSIDADE..., 2006).

The total metabolizable energy is expressed in kilocalories $\left(\mathrm{kcal} .100 \mathrm{~g}^{-1}\right)$. It was calculated considering Atwater's conversion factors: $(4 \times$ g protein $)+(4 \times$ g carbohydrates [total carbohydrates - food fiber] $)+(9 \times$ g total lipids $)$, as established by Latinfoods (LA RED..., 2002) and NEPA (UNIVERSIDADE..., 2006).

\section{Results and discussion}

The carbon contents in the mushrooms presented close values, even when grown in different residues (36.27-37.37 \%) (Table 1). Nitrogen content, however, was higher in the 
mushroom cultivated in sawdust, with values of 4.83 and $3.68 \%$ for SIAMP and SIAPB, respectively. $\mathrm{N}$ content in the mushroom grown in crushed sugar cane was $3.35 \%$, while the one grown in Bactris gasipaes Kunth residue presented N content of $2.73 \%$ and, consequently, lower protein content. The results agree with $\mathrm{N}$ values present in most mushrooms (2.27-5.13\%), according to Chang and Miles (1989).

Soluble solids present in the mushrooms varied according to cultivation substrates (Table 1). SIAMP, SIAPB, SIAPP and SIACN values were $2.64,1.64,3.64$ and $5.64 \%$, respectively; the highest content was found in substrates formulated from Bactris gasipaes Kunth and crushed sugar cane. Soluble solids contents are likely to be associated to the presence of B-complex hydrosoluble vitamins. Also, mushrooms are sources of vitamins, such as: the B-complex, ascorbic acid, and ergosterol that turns into vitamin $\mathrm{D}$ in the presence of ultraviolet light (CRISAN; SAND, 1978; GUNDE-CIMERMAN, 1999; BERNÁS; JAWORSKA; LISIEWKA, 2006; ÇAGLARIRMAK, 2007). However, analyses of the contents of these soluble solids and vitamins were not part of the objectives of this study.

Thiamin, riboflavin and niacin in P. ostreatus contents varied from 4.8-7.8, 4.7-4.9 and 55-109 mg.100 g ${ }^{-1}$ in dry weight, respectively, according to Çaglarirmak (2007). The ascorbic acid content was considered high for the Pleurotus genus, according to Breene (1990 apud ÇAGLARIRMAK, 2007) varying from $36 \%$ to $58 \%$ for $P$. ostreatus and $P$. sajor-caju, respectively.

$\mathrm{pH}$ values were practically similar among mushrooms cultivated in different substrates (6.25-6.48) (Table 1), as well as values corresponding to water activity (Wa), which varied from 0.57 to 0.59 . These $A a$ values are important to mushroom conservation because low water activity blocks microbial proliferation in processed (dry and pulverized) mushroom, as the microbial deterioration rate decreases as water activity gets close to 0.60 and there is no microbial growth below that value (EIRA, 2003).

The mushrooms with the highest nutritional facts are close to meat and milk, while the ones with the lowest nutritional facts

Table 1. Result of physical and chemical analyses (soluble solids, $\mathrm{pH}$, $\mathrm{Wa}$ ), carbon $(\mathrm{C})$, nitrogen $(\mathrm{N})$ and $\mathrm{C}: \mathrm{N}$ ratio of $P$. ostreatus mushroom grown in several substrates.

\begin{tabular}{|c|c|c|c|c|c|c|}
\hline \multirow[t]{2}{*}{$\begin{array}{l}\text { P. ostreatus grown in } \\
\text { several substrates }\end{array}$} & $\mathrm{C}$ & $\mathrm{N}$ & C:N & $\begin{array}{c}\text { Soluble } \\
\text { solids }\end{array}$ & $\mathrm{pH}$ & $\mathrm{Wa}$ \\
\hline & (\%) & (\%) & (\%) & ${ }^{\circ}$ Brix & & \\
\hline \multirow[t]{2}{*}{ SIAMP } & $(0,12)$ & $(0,02)$ & $(0,05)$ & & & \\
\hline & 36,27 & 4,83 & 7,51 & 2,64 & 6,48 & 0,59 \\
\hline \multirow[t]{2}{*}{ SIAPB } & $(0,07)$ & $(0,09)$ & $(0,25)$ & & & \\
\hline & 37,37 & 3,68 & 10,15 & 1,64 & 6,35 & 0,57 \\
\hline \multirow[t]{2}{*}{ SIAPP } & $(0,14)$ & $(0,06)$ & $(0,24)$ & & & \\
\hline & 37,37 & 2,73 & 13,69 & 3,64 & 6,25 & 0,58 \\
\hline \multirow[t]{2}{*}{ SIACN } & $(0,04)$ & $(0,12)$ & $(0,38)$ & & & \\
\hline & 37,03 & 3,35 & 11,05 & 5,64 & 6,33 & 0,57 \\
\hline
\end{tabular}

SIAMP: Mushroom cultivated using Simarouba amara Aubl. as substrate; SIAPB: Ochroma pyramidale as substrate; SIAPP: grinded and crushed Bactris gasipae stipe as substrate; SIACN: crushed sugar cane as substrate. Number in bold: average of three repetitions per analysis. Values in parentheses refer to standard deviation. present higher values than vegetables like carrot and tomato, but not soy (CRISAN; SANDS, 1978).

The N-to-protein conversion factor used to evaluate protein content was 4.38 , which takes into account the exclusion of non-protean $\mathrm{N}$ coming from the chitin of the cell wall of fungi (MILES; CHANG, 1997), instead of the 6.25 normally used for most food, thus avoiding protean overvalue.

Protein contents found in the mushrooms grown in the several substrates used in the present study (11.96-21.16\%) (Table 2) are within the range reported by Chang and Miles (1989) and Miles and Chang (1997), which varies from 10.5 to $30.4 \%$ of protein in dry basis for $P$. ostreatus, also agreeing with the results found by Sturion and Oetterer (1995), when they grew several Pleurotus species in several residues and obtained variations between 17.38 and $25 \%$. The results still agree with data from Ranzani and Sturion (1998), who analyzed different Pleurotus species grown in banana tree leaves that obtained variation from 17.4 to $24.1 \%$, and the results reached by Furlani (2004), who obtained about $22.22 \%$ of protein.

The highest protein contents of the mushrooms of the present study do not seem to be related to the highest protein contents found in the respective cultivation substrates, once the substrate with the highest protein content (SIAPP) yielded mushrooms with lower protein percentage (11.96\%), while the mushroom grown in Simarouba amara Aubl. as substrate presented protein percentage of $21.16 \%$ (Table 2). Similar results were obtained by Oliveira (2000), who grew two P. ostreatus strains in different agricultural residues with higher protein content. However, the substrate with the highest protein content did not yield mushrooms with higher protein content in both tested strains.

P. tuber-regium cultivation was tested by Fasidi and Ekuere (1993) in banana tree leaves, corncob, cotton residue and rice straw. The protein contents of the mushrooms grown in the respective dry residues were 16.8, 15.4, 15.1 and $13 \%$, respectively. The protein content of the mushroom grown in banana tree leaves is similar to the result presented for P. ostreatus grown in Ochroma pyramidale (16.12\%)(Table2).

Low results were found for lipids contents in the mushrooms grown in different residues (1.27-2,14\%), as presented in Table 2, in agreement with several studies (CHANG; MILES, 1989; STURION, 1994; STURION; OETTERER, 1995; MILES; CHANG, 1997; OLIVEIRA, 2000; SAPATA, 2005).

The results obtained were lower than the ones presented by Wang, Sakoda and Suzuki (2001), when the same species was grown in malted grains residue (4.3-4.7\% of lipid). They were also lower than the results found by Banik and Nandi (2004), who used wheat straw + manure from animal feces (7.97-13.94\% of lipid), and Furlani (2004) and Toro et al. (2006), who found variations from 2.46 to $5.8 \%$ and from 4.58 to $5.19 \%$ of lipids contents.

Fibers contents varied according to the cultivation substrate and they were considered higher than the values found by Sturion and Oetterer (1995) in three Pleurotus species (9.9$23.93 \%$ ) grown in different agricultural residues, mainly in 
Table 2. Result of the centesimal composition of $P$. ostreatus in different substrates.

\begin{tabular}{|c|c|c|c|c|c|c|c|c|c|c|}
\hline \multirow{3}{*}{$\begin{array}{c}\text { Mushroom } \\
\text { per substrate }\end{array}$} & \multirow{2}{*}{$\begin{array}{c}\text { Protein } \\
(\mathrm{N} \times 4,38)\end{array}$} & \multirow[t]{2}{*}{ Lipids } & \multirow{2}{*}{$\begin{array}{l}\text { Total } \\
\text { fiber }\end{array}$} & \multirow[t]{2}{*}{ Ashes } & \multicolumn{2}{|c|}{ Humidity } & \multirow{2}{*}{$\begin{array}{c}\text { Dry mass } \\
\text { (DM) }\end{array}$} & \multirow{2}{*}{$\begin{array}{c}\text { Total } \\
\text { carbohydrate }\end{array}$} & \multirow{2}{*}{$\begin{array}{c}\text { Available } \\
\text { carbohydrate }\end{array}$} & \multirow{2}{*}{$\begin{array}{c}\text { Total } \\
\text { metabolizable } \\
\text { energy }\end{array}$} \\
\hline & & & & & $\begin{array}{c}\text { Fresh } \\
\text { mushroom }\end{array}$ & $\begin{array}{c}\text { Dehydrated } \\
\text { mushroom }\end{array}$ & & & & \\
\hline & $(\%)$ & $(\%)$ & $(\%)$ & $(\%)$ & $(\%)$ & $(\%)$ & $(\%)$ & $(\%)$ & $(\%)$ & (Kcal) \\
\hline SIAMP & 21,16 & 1,27 & 18,89 & 8,97 & 92,00 & 10,89 & 89,11 & 57,71 & 38,82 & 251,32 \\
\hline SIAPBP & & $(0,04)$ & $(4,51)$ & $(0,32)$ & $(0,41)$ & $(0,08)$ & & & & \\
\hline SIAPP & 11,96 & 1,58 & 20,75 & 7,36 & 89,01 & 12,21 & 87,79 & 66,89 & 46,15 & 246,64 \\
\hline \multirow[t]{2}{*}{ SIACN } & & $(0,22)$ & $(1,17)$ & $(0,07)$ & $(1,77)$ & $(0,50)$ & & & & \\
\hline & 14,67 & 2,14 & 30,50 & 6,10 & 91,52 & 9,57 & 90,43 & 67,52 & 37,02 & 226,01 \\
\hline
\end{tabular}

SIAMP: Mushroom cultivated using Simarouba amara Aubl. as substrate; SIAPB: Ochroma pyramidale as substrate; SIAPP: grinded and crushed Bactris gasipae stipe as substrate; SIACN: crushed sugar cane as substrate. Numbers in bold: average of three repetitions per analysis. Values between parentheses refer to standard deviation.

SIAMP and SIACN (Table 2). They were also higher than the results found by Oliveira (2000) growing $P$. ostreatus in crushed sugar cane, elephant grass and banana tree leaves, with variations from 9.25 to $18.95 \%$ in fiber.

The fiber content of the mushroom grown in Ochroma pyramidale (Table 2) is similar to the ones found by Ragunathan and Swaminathan (2003) in three Pleurotus species grown in cotton residue in India (20.40 to $21.6 \%$ ). The values presented hereby are also higher than the percentages presented by Silva, Costa and Clemente (2002), Bonatti et al. (2004), Sapata (2005) and Toro et al. (2006), who worked with several Pleurotus species and obtained large variations in fibers content in their studies ( 4 to $9 \%$; 7.60 to $9.86 \%, 7.3-23.5 \%$; 11 to $11.9 \%$, respectively). They are still higher than the results found in Agaricus blazei (OLIVEIRA et al., 1999; SHIBATA; DEMIATE, 2003), with 9.28 to 10.13 and $14.57 \%$ for the respective studies.

The variation in ash content of the mushroom was 6.71 to $8.97 \%$ (Table 2). The highest ash content occurred in the mushroom grown in Simarouba amara Aubl. residue, being within the range cited by Chang and Miles (1989) and in agreement with Sturion (1994), Manzi et al. (1999), Oliveira (2000), Furlani (2004) and Sapata (2005). The results found were similar to the ones presented in the different A. blazei strains: 6.99 to $7.89 \%$ (SHIBATA; DEMIATE, 2003). On the other hand, they were higher than the values reported by Toro et al. (2006), when they worked with several species of Pleurotus grown in commercial substrate and obtained variation of 3.60 to $4.42 \%$ of ash. The values found were also higher than the ash content presented in P. tuber-regium (AKINDAHUNSI; OYETAYO, 2006 ), with 2.6 to $4.0 \%$ for stipe and pileus, respectively; and L. edodes (ANDRADE; MINHONI; ZIED, 2008), grown in different species of Eucalyptus, with variation from 2 to $5 \%$.

In relation to humidity, the values from 91.60 to $92 \%$ for fresh mushroom were considered normal, because mushrooms present about $90 \%$ of water in its composition (MAZIERO, 1990). The results in fresh base are within the range found by several Pleurotus strains (OLMEDO; MASOUD; ISASA, 1980; MILES; CHANG, 1997; MANZI et al., 1999; RAGUNATHAN; SWAMINATHAN, 2003; GBOLAGADE et al., 2006). The humidity of dry mushroom varied from 9.57 to $10.89 \%$, in agreement with the results by Oliveira et al. (1999) and Shibata and Demiate (2003) for dry A. blazei.

Total carbohydrates results (fiber fraction included) for mushroom samples SIAMP, SIAPB, SIAPP and SIACN were $57.71,63.47,66.89$ and $67.52 \%$, respectively, with the highest results found in the mushrooms grown in Bactris gasipaes Kunth (SIAPP) and crushed sugar cane (SIACN) residues. Those results occurred due to the high amount of total fiber $(20.75$ and $30.50 \%$ ) present in the respective samples, which are part of the total carbohydrates, as well as to the low protein contents present in those samples.

The highest carbohydrates contents available (fiber fraction excluded) were found in SIAPP and SIAMP samples (46.15 and $38.82 \%$, respectively) (Table 2 ), due to the lower fiber percentages.

The higher the available carbohydrate and protein percentages present in the sample, the higher the total metabolizable energy. Carbohydrate and protein were found in higher amounts in SIAMP and SIAPP, with 251.32 and $246.64 \mathrm{Kcal}$ for the respective samples. The results were lower than the ones reported by Miles and Chang (1997) for P. ostreatus.

A general analysis of the samples allowed the observation of a great variation in protein, lipid, ash, total carbohydrate, available carbohydrate and energy compositions in the mushrooms grown in all cultivation substrates, in agreement with several studies (FASIDI; EKUERE, 1993; STURION; OETTERER, 1995; WANG; SAKODA; SUZUKI, 2001; SILVA; COSTA; CLEMENTE, 2002; FURLANI, 2004; SAPATA, 2005; DAS; MUKHERJEE, 2007).

The study performed in Japan (WANG; SAKODA; SUZUKI, 2001) with $P$. ostreatus cultivation using several malted grains species presented total carbohydrates varying from 35.7 to $45.5 \%$ and energy varying from 325.6 to $34168 \mathrm{Kcal}$. Those results were lower than the ones found in the present study (57.71 to $67.52 \%)$. However, the total metabolizable energy was lower in this study ( 211.86 to $251.32 \mathrm{kcal}$ ), mainly because available carbohydrates were not presented in the study of the authors.

Bonatti et al. (2004) analyzed the centesimal composition of $P$. ostreatus and $P$. sajor-caju in banana tree straw residue and 
reported a reduction in the second flow for both mushrooms, except for humidity and gross fiber, which were higher in the second flow for P. sajor-caju only. Humidity, lipid, total carbohydrates, ash, fiber, total nitrogen and total protein contents for the mushrooms studied by those authors varied from 83.17 to $88.06,2.24$ to $5.97,40.53$ to $46.97,4.08$ to 5.58 , 7.60 to $9.45,3.7$ to 4.20 and 16.21 to $18.40 \%$, respectively. By comparing those results with the ones of present work, we could observe that the lipid values were higher than in the present study, while humidity, carbohydrates, ash and fiber were lower. Protein (Table 2) and N (Table 1) values were found within similar ranges.

The same P. ostreatus and P. sajor-caju strains were tested by Bonatti et al. (2004), grown in banana tree straw and rice straw. The same analyses presented in the prior study were carried out by Bonatti et al. (2004), but only for the first production flow. The comparative results showed that lipids contents found by the authors were higher (5.26 to 6.32\%) than in the present study (Table 2). Total carbohydrates (43 to $47 \%$ ), ash (5.14 to $6.13 \%$ ) and total fiber (7.60 to 9.86\%) contents were surpassed again. Protein (13.1 to $18.4 \%$ ) results were similar to the present study, except for the mushroom grown in Simarouba amara Aubl., which presented higher protein value than the one found by those authors (21.16\%) (Table 2). N percentages were also similar (2.96 to $3.85 \%)$, except for the mushroom grown in Simarouba amara Aubl. residue, which was higher (Table 1).

Sapata (2005) evaluated the composition of P. ostreatus grown in different agricultural residues and found variations in fiber (5.1 to $23.5 \%$ ), total carbohydrates ( 37.8 to $50.7 \%$ ), ash (5.3 to $8.3 \%$ ), lipids (1.7 to $2.0 \%$ ) and proteins (18.4 to $27.4 \%)$. By comparing the results of the author with the ones in Table 2, we verified that fiber (18.86 to $31.30 \%$ ) and total carbohydrate (57.71 to $67.52 \%$ ) contents are lower than the present ones; ash (6.10 to $8.97 \%$ ) and lipids (1.27 to $2.14 \%$ ) contents were similar; and protein content (11.96 to $21.16 \%$ ) was higher. However, it is important to emphasize that the protean analysis of the mushrooms of the present study was carried out by homogenizing all the mushrooms collected in all productive flows for each cultivation substrate, while the analyses performed in most of the works consulted here considered the mushrooms collected in the first flow only, resulting in higher protein contents due to the higher amount of nutrients in the substrate at that stage.

It is known that high nutritional composition of mushrooms is usually related to the pileus instead of the stipe, as proved in the studies carried out by Shibata and Demiate (2003), with A. blazei, and Akindahunsi and Oyetayo (2006), with P. tuber-regium. Akindahunsi and Oyetayo (2006) proved it in relation to protein, lipids, ash and total carbohydrates in P. tuber-regium. However, the results found for pileus and stipe, respectively, for protein (13.8 and 7.8\%), lipids (1.2 and $0.7 \%$ ), ash (4.9 and 2.6\%) and total carbohydrates (53.2 and 34\%) were lower than the same compositions presented by P. ostreatus grown in the different substrates used in the present study analyzing the mushroom as a whole (Table 2).

Oliveira et al. (1999) determined humidity, lipids, ash, raw fiber, available carbohydrates, and proteins contents in
A. blazei and obtained the following results: $9.67 \%, 1.48 \%$, $9.37 \%, 14.57 \%, 34.78 \%$ and $30.13 \%$, respectively. Humidity, lipids and ash were similar to the ones obtained in the present study (Table 2). Values for fiber and available carbohydrates were lower than $P$. ostreatus in the present study. As for protein, however, authors used $\mathrm{N} \times 6.25$ factor to convert $\mathrm{N}$ into protein, resulting in protein overvalue for that mushroom (30.13\%). By using the 4.38 factor for A. blazei, the value of $21.11 \%$ of protein would have been found, similar to the one found in P. ostreatus grown in Simarouba amara Aubl. residue. This equivalence in the protein contents of A. blazei and P. ostreatus is frequently disseminated by scientific reports and the media.

P. ostreatus is considered very important food with great nutritional value to be used in high-protein and low-lipid diets, due to its high fiber (18.89\% to $31.30 \%$ ), protein (11.96 to $21.16 \%$ ), total carbohydrates (57 to $67.52 \%$ ), available carbohydrates ( 32.12 to $46.15 \%$ ) and total metabolizable energy ( 211.86 to $251.32 \mathrm{Kcal}$ ) values and low lipids (1.27 to $2.14 \%$ ) contents.

\section{Conclusions}

The nutritional composition of $P$. ostreatus varied according to the cultivation substrate.

P. ostreatus can be considered important food due to its nutritional features: high protein, metabolizable carbohydrates and fiber contents and low lipids and calories contents.

\section{References}

AKINDAHUNSI, A. A.; OYETAYO, F. L. Nutrient and antinutrient distribution of edible mushroom, Pleurotus tuber-regium (fries) Singer. Food Science and Technology, v. 39, n. 5, p. 548-553, 2006.

ANDRADE, M. C. N.; MINHONI, M. T. A.; ZIED, D. C. Avaliação nutricional do cogumelo shiitake [Lentinula edodes (Berk.) Pegler] em função da linhagem e do tipo de eucalipto cultivado. Ciência e Tecnologia de Alimentos, v. 28, n. 4, p. 916-921, 2008. http:// dx.doi.org/10.1590/S0101-20612008000400024

ASSOCIATION OF OFFICIAL ANALYTICAL CHEMISTS - AOAC. Official Methods of Analysis of A.O.A.C. 16th ed. Versão 3. Gaithersburg: AOAC International, 1997.

BANIK, S.; NANDI, R. Effect of supplementation of rice straw with biogás residual slurry manure on the yield, protein and mineral contents of oyster mushroom. Industrial Crops and Products, v. 20, n. 3, p. 311-319, 2004. http://dx.doi.org/10.1016/j. indcrop.2003.11.003

BERNÁS, B.; JAWORSKA, G.; LISIEWKA, Z. Edible Mushrooms as a souce of valuable nutritive constituintes. Acta Scientiarum Polunorum Technologia Alimentaria, v. 5, n.1 p. 5-20, 2006.

BONATTI, M. et al. Evaluation of Pleurotus ostreatus and Pleurotus sajorcaju nutritional characteristics when cultivated in different lignocellulosic wastes. Food Chemistry, v. 88, n. 3, p. 425-428, 2004. http://dx.doi.org/10.1016/j.foodchem.2004.01.050

BRASEQ - BRASILEIRA DE EQUIPAMENTOS. Entendendo a atividade de água e sua importância para a qualidade de alimentos e outros produtos em geral. Jarinu: BRASEQ LTDA. (Boletim técnico informativo Braseq). Disponível em: $<$ www.braseq. com.br> Acesso em: 20 jul. 2005. 
CARVAlHO, H. H. et al. Alimentos: métodos físicos e químicos de análise. Porto Alegre: Ed. UFRGS, 2002.

ÇAGLARIRMAK, N. The nutrients of exotic mushrooms (Lentinula edodes and Pleurotus species) and an estimated approach to the volatile compounds. Food Cheminstry, v. 105, n. 3, p. 1188-1184, 2007. http://dx.doi.org/10.1016/j.foodchem.2007.02.021

CHANG, S. T.; MILES, P. G. Edible mushrooms and their cultivation. Boca Raton: CRC Press Inc.,1989.

COCHRAN, K. W. Medical effects. In: CHANG, S. T.; HAYES, W.A. (Eds). The biology and cultivation of edible mushroom. New York: Academic Press, 1978. p. 169-187.

CRISAN, E. V.; SANDS, A. A nutritional value: In: CHANG, S. T.; HAYES, W. A. (Eds). The biology and cultivation of edible mushroom. New York: Academic Press, 1978, p. 137-168.

DAS, N.; MUKHERJEE, N. Cultivation of Pleurotus ostreatus on weed plant. Bioresource Technology, v. 98, p. 2723-2726, 2007. PMid:17161599. http://dx.doi.org/10.1016/j.biortech.2006.09.061

EIRA, A. F. Cultivo do cogumelo medicinal Agaricus blazei (Murril) ss. Heinemann ou Agaricus brasiliensis (Wasser et al.). Viçosa: Aprenda Fácil Editora, 2003.

FASIDI, I. O.; EKUERE, U. U. Studies on Pleurotus tuber-regium (Fries) Singer: cultivation, proximate composition and mineral contents of sclerotia. Food Chemistry, v. 48, n. 3, p. 255-258, 1993. http:// dx.doi.org/10.1016/0308-8146(93)90136-4

FURLANI, R. P. Z. Valor Nutricional de cogumelos cultivados no Brasil. 2004. 88 f. Tese (Doutorado em Ciência de Alimentos)Faculdade de Engenharia de Alimentos, Universidade Estadual de Campinas, Campinas, 2004.

GBOLAGADE, J. et al. Nutritive value of common wild edible mushrooms from nouthern Nigeria. Global Journal of Biotechnology \& Bichemistry, v. 1, n. 1, p. 16-21, 2006.

GUNDE-CIMERMAN, N. Medicinal value of genus Pleurotus (Fr.) P. Karst. (Agaricales s. 1., Basidiomycetes). Internatational Journal of Medicinal Mushrooms, v. 1, p. 60-80, 1999.

KURTZMAN, R. H.; ZADRAZIL, F. Physiological and taxonomic considerations for cultivation of Pleurotus mushrooms. In: CHANG, S. T.; QUIMIO, T. H. (Eds.). Tropical mushrooms: Biological nature and cultivation methods. Hong Kong: The Chinese University Press., 1982. p. 299-348.

LA RED DE LATINOAMERICANA DE COMPOSICIÓN DE ALIMENTOS - LATINFOODS. Tabla de Composicion de Alimentos de América Latina. 2002. Disponível em <htt://www. fao.org/LAmerica/grupo.htm>. Acesso em: 20 mai. 2006.

MALAVOLTA, E.; VITTI, G. C.; OLIVEIRA, S. A. Avaliação do Estado Nutricional das Plantas: Princípios e Aplicações. Piracicaba: Associação Brasileira para Pesquisa da Potassa Fosfato Piracicaba, 1989.

MANZI, P. et al. Nutrients in edible mushrooms: an inter-species comparative study. Food Chemistry, v. 65, n. 4, p. 477-482, 1999. http://dx.doi.org/10.1016/S0308-8146(98)00212-X

MAZIERO, R. Substratos alternativos para o cultivo de Pleurotus spp. 1990. 136 f. Dissertação (Mestrado em Ciências Biológicas)Instituto de Biociências, Universidade de São Paulo, São Paulo, 1990.

MENDONÇA, E. S.; MATOS, E. S. Matéria Orgânica do Solo: Métodos de Análises. Viçosa: UFV, 2005.

MILES, P. G.; CHANG, S. T. Mushroom biology: concise basics and current developments. Singapore: World Scientific, 1997. http:// dx.doi.org/10.1142/9789812839794
MINHONI, M. T. A. et al. Cultivo de Lentinula edodes (Berk.) Pegler - (Shiitake). 3. ed. Botucatu: FEPAF, 2007.

OLIVEIRA, E. C. M. et al. Composição centesimal do cogumelo do Sol (Agaricus blazei). Revista da Universidade de Alfenas, v. 5, p. 169-172, 1999.

OLIVEIRA, H. C. B. Avaliação de três substratos com diferentes granulométricas, para o cultivo de duas linhagens de Pleurotus ostreatus (Jacq.:Fr.) Kummer. 2000. 89 f. Dissertação (Mestrado em Agronomia)-Universidade Federal do Ceará, Fortaleza, 2000.

OLMEDO, R. G.; MASOUD, T. A.; ISASA, M. E. T. Macro e micronutrientes em hongos comestibles. 1. Macronutrientes. Anales de Bromatologia, v. 32, n. 2, p. 145-168, 1980.

RAGUNATHAN, R.; SWAMINATHA, K. Nutritional status of Pleurotus spp. grown on various agro-wastes. Food Chemistry, v. 80 , n. 3 , p. $371-375,2003$. http://dx.doi.org/10.1016/S03088146(02)00275-3

RANZANI, M. R. T.; STURION, G. L. Avaliação da composição em aminoácidos de Pleurotus spp. cultivados em folha de bananeira. Archivos Latino americanos de Nutricion, v. 48, n. 4, p. 339-348, 1998.

SALES-CAMPOS, C. Aproveitamento de resíduos madeireiros e da agroindústria regional para o cultivo de fungos comestíveis de ocorrência na região amazônica. 2008. 182 f. Tese (Doutorado em Biotecnologia), Universidade Federal do Amazonas, Manaus, 2008.

SAPATA, M. R. L. Valorização de resíduos agrícolas: produção de cogumelos do gênero Pleurotus. Oeiras: Instituto Nacional de Investigação Agrária e das Pescas, Estação Agronômica Nacional, 2005. 32 p. Relatório Final de Projeto.

SHIBATA, C. K. R.; DEMIATE, I. M. Cultivo e análise da composição química de cogumelo do sol (Agaricus blazei Murril). Ciências Biológicas e da Saúde, v. 9, n. 2, p. 21-32, 2003.

SILVA, S. O.; COSTA, S. M. G.; CLEMENTE, E. Chemical composition of Pleurotus pulmonarius (Fr.) Quél., substrates and residue after cultivation. Brazilian Archives of Biology and Technology, v. 45, n. 4, p. 531-535, 2002.

SMITH, J. E.; ROWAN, N. J.; SULLIVAN, R. Medicinal mushrooms: a rapidly developing area of biotechnology for cancer therapy and other bioactivities (Review). Biotechnology Letters, v. 24, n. 22, p. 1839-1845, 2002. http://dx.doi.org/10.1023/A:1020994628109

STURION, G. L. Utilização da folha da Bananeira como substrato para o cultivo cogumelos comestíveis (Pleurotus spp). 1994. $147 \mathrm{f}$. Dissertação (Mestrado em Ciências)-Escola Superior de Agricultura Luiz de Queiroz, Universidade de São Paulo, Piracicaba, 1994.

STURION, G. L.; OETTERER, M. Composição química de cogumelos comestíveis (Pleurotus spp) originados de cultivo em diferentes substratos. Ciência e Tecnologia de Alimentos, v. 15, n. 2, p. 189193, 1995.

TORO, G. V. et al. Biological quality of proteins from three strains of Pleurotus spp. Food Chemistry, v. 94, n.4, p. 494-497, 2006. http:// dx.doi.org/10.1016/j.foodchem.2004.11.053

UNIVERSIDADE DE CAMPINAS - UNICAMP. Tabela brasileira de composição de alimentos - TACO. Versão 2. 2. ed. Campinas: UNICAMP/NEPA, 2006.

WANG, D.; SAKODA, A.; SUZUKI, M. Biological efficiency and nutritional value of Pleurotus ostreatus cultivated on spent beer grain. Bioresource Technology, v. 78, n. 3, p. 293-333, 2001. http:// dx.doi.org/10.1016/S0960-8524(01)00002-5 